Vol. 4, No. 1, Maret 2020, Hal. 77-83

\title{
PENDAMPINGAN UPAYA MENURUNKAN INKONTINENSIA URIN BAGI MASYARAKAT DI TALANG BETUTU PALEMBANG
}

\author{
Dheni Koerniawan ${ }^{1}$, Srimiyati ${ }^{2}$, Aniska Indah Fari ${ }^{3}$, Sanny Frisca ${ }^{4}$, \\ Wendi Putra Pratama ${ }^{5}$ \\ ${ }^{1}$ Prodi Ilmu Keperawatan dan Ners, Universitas Katolik Musi Charitas, Indonesia \\ 1dheni@ukmc.ac.id, ${ }^{2}$ srimiyati@ukmc.ac.id, ${ }^{3}$ aniska@ukmc.ac.id, ${ }^{4}$ sanny@ukmc.ac.id, \\ wendi@ukmc.ac.id
}

\begin{abstract}
ABSTRAK
Abstrak: Inkontinensia urine menjadi salah satu masalah yang meluas dan merugikan terutama bagi lansia. Salah satu bentuknya seperti lansia akan merasa rendah diri karena selalu basah akibat urine yang keluar, mungkin pada saat batuk, bersin, mengangkat barang berat dan ketidakmampuan menahan buang air kecil. Senam Kegel yang merupakan terapi non farmakologi untuk mengatasi inkontinensia urin. Kegiatan pengabdian yang dilakukan bertujuan untuk melatih lansia untuk melakukan senam Kegel sehingga dapat mengurangi gejala inkontinensia urin. Kegiatan dilakukan dengan pemberian edukasi, latihan senam Kegel, dan pendampingan selama tiga pertemuan. Hasil kegiatan menunjukkan bahwa mitra mengalami penurunan ketidakmampuan menahan kemih dari rerata 8,56 menjadi 6,3 dan penurunan frekuensi berkemih dari rerata 2,07 menjadi 1,44 serta rerata skor total inkontinensia urine menurun dari 10,63 menjadi 7,74.
\end{abstract}

Kata kunci: Lansia; Inkontinensia urin; Senam Kegel

Abstract: Urinary incontinence is a widespread and detrimental problem especially for the elderly. One form such as the elderly will feel inferior because it is always wet due to urine coming out, maybe when coughing, sneezing, lifting heavy objects and the inability to resist urination. Kegel exercises which is a non-pharmacological therapy for overcoming urinary incontinence. Community service activities was aimed to train elderly for doing Kegel exercise thus can reduce symptoms of urinary incontinence. Service were carried out by providing education, Kegel exercises, and mentoring for three meetings. The results of the activity showed that the partners experienced a decrease in the inability to hold urine from an average of 8.56 to 6.3 and a decrease in the frequency of urination from a mean of 2.07 to 1.44 and the mean total urinary incontinence score decreased from 10.63 to 7.74

Keywords: Elderly, Urine incontinence, Kegel exercise

Article History:

Received: 31-01-2020

Revised : 19-02-2020

Accepted: 24-02-2020

Online : 03-03-2020

This is an open access article under the $C C-B Y-S A$ license 


\section{A. LATAR BELAKANG}

Proses penuaan merupakan suatu proses biologis yang tidak dapat dihindari dan akan dialami oleh setiap orang. Masalah kesehatan yang sering dijumpai adalah Inkontinensia urine yaitu pengeluaran urine involunter yang menimbulkan masalah kebersihan dan masalah sosial (Wilis, 2018). Baik pria maupun wanita pasti mengalami penurunan fungsi pada sistem perkemihan. Hal ini diakibatkan oleh penurunan tonus otot vagina dan otot pintu saluran kemih (uretra) karena penurunan hormon estrogen sehingga keluarnya urine tidak dapat dikontrol (Wente \& Dolan, 2018).

Seiring dengan bertambahnya usia mengakibatkan terjadinya perubahan anatomi dan fungsi organ kemih antara lain disebabkan oleh melemahnya otot dasar panggul, kebiasaan mengejan yang salah ataupun karena penurunan hormon estrogen pada usia 45 tahun ke atas menyebabkan terjadinya penurunan tonus otot pubocoxygeal dan otot pintu saluran kemih uretra (Siburian, 2013). Kelemahan otot dasar panggul dapat juga terjadi karena kehamilan, karena proses persalinan membuat otot dasar panggul rusak akibat regangan otot dan jaringan penunjang serta robekan jalan lahir, kegemukan (obesitas), dan menopause dapat meningkatkan terjadinya inkontinensia urine (Firyal, 2017).

Masalah kesehatan ini yang cukup sering dijumpai pada orang berusia lanjut, khususnya perempuan. Inkontinensia urine sering kali tidak dilaporkan oleh pasien atau keluarganya, antara lain karena menganggap bahwa masalah tersebut merupakan masalah yang memalukan atau tabu untuk diceritakan (Felde, Ebbesen, \& Hunskaar, 2017). Ketidaktahuan masyarakat tentang masalah inkontinensia urine, masyarakat menganggap kondisi tersebut merupakan sesuatu yang wajar dan tidak perlu diatasi.

Inkontinensia urine merupakan pengeluaran urine involunter (tidak disadari/mengompol) pada waktu dan tempat yang tidak tepat di luar keinginan. Inkontinensia urine adalah pengeluaran urine secara spontan pada sembarang waktu di luar kehendak (involunter). Keadaan ini umumnya dijumpai pada lansia. Terjadinya kelemahan atau penurunan otot dasar panggul inilah yang memicu terjadinya inkontinensia urine yaitu buang air kecil (Stanley, 2007).

Prevalensi inkontinensia urin di Indonesia telah mencapai 5,8\% dari keseluruhan penduduk (Juananda \& Febriantara, 2017). Sekalipun demikian penanganannya masih belum maksimal. Kondisi ini juga terjadi di Kelurahan Talang Betutu hingga kini masih banyak warga yang mengeluhkan sering tidak mampu menahan bila ingin buang air kecil (beser).

Permasalahan ini sampai saat ini belum teratasi dengan baik. Sebagian warga mengaku bahwa dirinya juga sudah berobat tetapi belum mengatasi. Sementara untuk mengatasi keluhan terhadap penurunan sistem perkemihan tersebut dapat dilakukan dengan mudah dan murah serta tanpa obat-obatan. Salah satu cara yang dapat dilakukan adalah latihan otot dasar panggul (pelvic muscle exercise) atau disebut latihan Kegel (Crisp, Douglas, Rebeiro, \& Waters, 2017), (Strong, Salim, Nickels, \& Poduri, 2017). Latihan dasar panggul ini melibatkan kontraksi tulang otot pubokoksigeus, otot yang membentuk struktur penyokong panggul dan 
mengelilingi pintu panggul pada vagina, uretra, dan rektum pada akhirnya memperbaiki ketidakmampuan berkemih yang terkontrol.

Oleh karena itu, dengan melatih senam Kegel dapat menjadi solusi bagi mitra untuk meningkatkan kemampuan mengontrol dalam berkemih. Kegiatan pengabdian kepada masyarakat bertujuan untuk melatih lansia senam Kegel untuk mengurangi gejala inkontinensia urin

\section{B. METODE PELAKSANAAN}

Kegiatan pengabdian kepada masyarakat (Abdimas) dilakukan dengan melakukan survei awal yang kemudian dilanjutkan dengan persetujuan mitra terhadap diadakannya kegiatan Abdimas serta perencanaan pelaksanaan kegiatan. Edukasi, latihan, dan pendampingan dilakukan pada kegiatan inti Abdimas yang kemudian dilakukan evaluasi kondisi inkontinensia urine yang dialami mitra, meliputi aspek ketidakmampuan menahan berkemih dan frekuensi berkemih.

Survei awal dilakukan 2 minggu sebelumnya untuk menilai kemampuan menahan berkemih dan frekuensi inkontinensia urin selama sehari dalam kurun waktu 1 bulan terakhir. Selanjutnya, pertemuan dilakukan di rumah ketua RT setempat yang dapat memfasilitasi sebanyak 30 lansia untuk dapat melakukan olahrga senam kegel bersama. Persiapan dilakukan sehari sebelum pelaksanaan untuk mendesain lokasi senam sehingga pada pelaksanaan lansia dapat berbaring dengan nyaman.

Pendampingan dilakukan selama satu minggu terhadap 30 lansia, pertemuan dilakukan 3 kali dalam seminggu dengan pemberian edukasi dan pendampingan terhadap lansia. Pada pertemuan pertama diberikan edukasi tentang latihan kegel berupa tampilan gambar dan gerakan gerakan senam. Selain itu dilakukan demonstrasi oleh instruktur cara melakukan gerakan yang tepat dan aman. Setelahnya dilakukan latihan bersama untuk semua gerakan senam dan pendampingan oleh para fasilitator. Pertemuan berikutnya dilakukan 2 hari dan 4 hari setelahnya untuk menilai kemampuan melakukan senam kegel dan mengevaluasi kemajuan dalam menahan berkemih. Lansia sudah mampu melakukan senam kegel secara mandiri dan sudah menerapkan di rumah. Lansia menyatakan bahwa sudah ada perubahan dalam menahan berkemih.

\section{HASIL DAN PEMBAHASAN}

\section{Survei Awal}

\section{a. Pengalaman Kebocoran Urin}

Survei awal dilakukan sebelum Latihan senam Kegel. Survei ini bertujuan untuk mengidentifikasi kondisi inkontinensia urin yang dialami oleh mitra. Identifikasi yang pertama meliputi pengalaman kebocoran urin selama 4 minggu terakhir, frekuensi berkemih yang tidak terkontrol, dan jumlah volume urin yang keluar secara ratarata selama 4 minggu terakhir.

Tabel 1. Distribusi Pengalaman Kebocoran Urin Selama 4 Minggu Terakhir

\begin{tabular}{|c|c|c|c|}
\hline No. & Kategori & $\begin{array}{l}\text { Frekuensi } \\
\text { (orang) }\end{array}$ & $\begin{array}{c}\text { Persentase } \\
(\%)\end{array}$ \\
\hline 1. & \multicolumn{3}{|c|}{ Pengalaman berkemih tidak terkontrol } \\
\hline & $\mathrm{Ya}$ & 30 & 100 \\
\hline
\end{tabular}




\begin{tabular}{|c|c|c|c|}
\hline No. & Kategori & $\begin{array}{l}\text { Frekuensi } \\
\text { (orang) }\end{array}$ & $\begin{array}{l}\text { Persentase } \\
(\%)\end{array}$ \\
\hline & Tidak & 0 & 0 \\
\hline \multicolumn{4}{|c|}{ Frekuensi berkemih selama 4 minggu terakhir } \\
\hline & Tidak pernah & 0 & 0 \\
\hline & 1 minggu sekali atau kurang & 0 & 0 \\
\hline & $2-3$ kali seminggu & 0 & 0 \\
\hline & 1 kali dalam sehari & 0 & 0 \\
\hline & Beberapa kali dalam sehari & 30 & $100 \%$ \\
\hline 3. & \multicolumn{3}{|c|}{ Jumlah berkemih tidak terkontrol selama 4 minggu terakhir } \\
\hline & Sangat sedikit & 1 & 3 \\
\hline & $\begin{array}{l}\text { Sejumlah sedikit urin yang } \\
\text { keluar }\end{array}$ & 21 & 70 \\
\hline & Urin keluar lumayan banyak & 8 & 27 \\
\hline & $\begin{array}{l}\text { Urin yang keluar dalam jumlah } \\
\text { banyak }\end{array}$ & 0 & 0 \\
\hline
\end{tabular}

Hasil survei awal pada Tabel 1 menunjukkan bahwa ebagian besar mitra mengalami inkontinensia urin (30 orang [100\%]) dengan frekuensi beberapa kali dalam satu hari (30 orang [100\%]), dan sedikit jumlah urin yang keluar (21 orang [70\%]). Perubahan yang dialami oleh mitra terjadi karena lansia cenderung mengalami penurunan fungsi tubuh baik secara anatomis maupun fisiologis, termasuk pada sistem perkemihan penurunan kekuatan otot dasar panggul yang dapat disebabkan oleh perubahan struktur sel otot dan juga faktor hormon pada masa menopause (Tortora, 2009), (Sun \& Agrawal, 2016). Kondisi tersebut selanjutnya memunculkan manifestasi kurangnya kontrol dalam berkemih sehingga mitra tidak mampu mengatur berkemih sesuai dengan kehendaknya.

\section{b. Dampak Terhadap Aktivitas Sehari-hari}

Hasil survei yang kedua adalah dampak inkontinensia urin yang dialami oleh mitra terhadap aktivitas sehari-harinya selama 4 minggu terakhir. Respon mitra digambarkan dalam rentang 0 berarti Tidak Mengganggu (TM) dan 10 berarti Sangat Mengganggu (SM). Adapun hasilnya sesuai Tabel 2 berikut.

Tabel 2. Distribusi Dampak Kebocoran Urin

\begin{tabular}{lccccccccccc}
\hline \multicolumn{1}{c}{ Skala } & $\mathbf{0}$ & $\mathbf{1}$ & $\mathbf{2}$ & $\mathbf{3}$ & $\mathbf{4}$ & $\mathbf{5}$ & $\mathbf{6}$ & $\mathbf{7}$ & $\mathbf{8}$ & $\mathbf{9}$ & $\mathbf{1 0}$ \\
\hline & TM & & & & & & & & & & SM \\
\hline Frekuensi (orang) & 0 & $\delta$ & 0 & 0 & 1 & 1 & 4 & 3 & 18 & 3 & 0 \\
\hline Persentase (\%) & 0 & 0 & 0 & 0 & 3 & 3 & 13 & 10 & 60 & 10 & 0 \\
\hline
\end{tabular}

Berdasarkan Tabel 2 di atas diperoleh informasi bahwa inkontinensia urin yang dialami mitra dirasakan berdampak pada aktivitas sehari-hari, seperti tampak pada Tabel 2 dengan sebagian besar mitra memiliki skala 8 sebanyak 18 orang (60\%), dengan rentang skala 4 sampai dengan 9 . 


\section{Perubahan Kondisi Inkontinensia Urin Pada Mitra}

Latihan senam Kegel selama tiga kali pertemuan serta dianjurkan kepada mitra untuk dilakukan di rumah. Mitra diidentifikasi dalam dua aspek, yatiu ketidakmampuan menahan kemih dan frekuensi berkemih. Data diukur melalui dua tahapan, yaitu sebelum latihan (pre-test) dan setelah latihan (post-test). Tingkat Penurunan (P), Ketidakmampuan Menahan Kemih (KMK), serta Frekuensi Berkemih (FB) dapat dilihat pada Tabel 3 berikut.

Tabel 3. Perubahan Inkontinensia Urin Sebelum dan Sesudah Latihan Kegel

\begin{tabular}{|c|c|c|c|c|c|c|c|c|c|}
\hline \multirow{2}{*}{ Statistik } & \multicolumn{2}{|c|}{ KMK } & \multirow{2}{*}{$\mathbf{P}$} & \multicolumn{2}{|c|}{ FB } & \multirow{2}{*}{$\mathbf{P}$} & \multicolumn{2}{|c|}{ Nilai Total } & \multirow{2}{*}{$\mathbf{P}$} \\
\hline & Pre & Post & & Pre & Post & & Pre & Post & \\
\hline Rerata & 8,56 & 6,30 & 2,26 & 2,07 & 1,44 & 0,63 & 10,63 & 7,74 & 2,89 \\
\hline Median & 8 & 6 & 2 & 2 & 1 & 1 & 11 & 7 & 3 \\
\hline Modus & 11 & 6 & 5 & 2 & 1 & 1 & 14 & 11 & 5 \\
\hline Min & 5 & 3 & 2 & 1 & 1 & 0 & 6 & 4 & 0 \\
\hline Maks & 12 & 10 & 4 & 3 & 3 & 2 & 15 & 12 & 5 \\
\hline
\end{tabular}

Tabel 3 menunjukkan bahwa setelah diberikan pendampingan latihan Kegel, mitra mengalami penurunan skor dalam ketidakmampuan menahan berkemih pada nilai rerata (skor 2,26), nilai tengah (skor 2), skor yang paling banyak (skor 5), bahkan ada mitra yang sudah mulai mampu menahan berkemihnya (skor 2). Begitu pula pada skor frekuensi berkemih yang juga mengalami penurunan pada nilai rerata (skor 0,63), nilai tengah dan nilai paling banyak muncul (skor 1). Skor total juga menunjukkan penurunan skor yang signifikan pada tiap aspek data.

Senam Kegel bertujuan untuk melatih atau menguatkan otot-otot dasar panggul yang melibatkan kontraksi tulang otot pubokoksigeus, otot yang membentuk struktur penyokong panggul dan mengelilingi pintu panggul pada vagina, uretra, dan rectum (pelvic floor muscle), serta untuk meringankan berbagai gejala yang timbul akibat dari kelemahan otot dasar panggul (pelvic floor muscle), seperti stres saluran kencing, inkontinensia dan prolaps organ panggul, serta untuk meningkatkan respon seksual $[10,6,11]$. Latihan Kegel juga telah terbukti dari beberapa hasil penelitian dapat meningkatkan kemampuan untuk mengontrol berkemih sehingga frekuensi mengompol pun berkurang (Johan, 2011), (D.A \& Martiningsih, 2014), (Karjoyo, Pangemanan, \& Onibala, 2017),

Latihan ini akan meningkatkan kemampuan mengontrol dan mengatasi ejakulasi dini, ereksi yang lebih kuat dan meningkatkan kepuasan seksual saat orgasme. Selain itu multipel orgasme juga bisa dialami oleh pria sebagai hasil dari latihan senam kegel yang dilakukan secara teratur. Pada pria, senam ini juga akan mengangkat testis dan mengencangkan otot kremaster sama seperti mengencangkan sfingter ani. Latihan pada otot memicu proliferasi sel otot dan matriks jaringan ikat sehingga dapat meningkatkan tonus otot (Chiacchiero, et al, 2010), (Pranata, Koerniawan, \& Daeli, 2019). 


\section{SIMPULAN DAN SARAN}

Penurunan fungsi sistem organ tubuh merupakan hal yang wajar ketika usia makin bertambah, termasuk kemampuan kontraksi otot dasar panggul yang membantu dalam mengontrol berkemih. Hal ini tampak pada hasil survei awal mitra yang seluruhnya mengalami inkontinensia urin (kebocoran urin atau mengompol) (30 orang; 100\%) dengan frekuensi beberapa kali dalam sehari (30 orang; 100\%), serta sebagian besar sejumlah sedikit urin yang keluar (21 orang; 70\%), terdapat juga yang keluar dengan jumlah sangat sedikit (1 orang; $3 \%$ ) dan dalam jumlah banyak (8 orang; $27 \%)$. Mitra juga mengungkapkan kondisi inkontinensia urin mengganggu aktivitas sehari-harinya, yang sebagian besar memilih skala 8/10 (18 orang; $60 \%$ ) dengan rentang skala 4 (1 orang; $3 \%$ ) hingga skala 9 (3 orang; $10 \%)$. Namun, setelah dilakukan senam Kegel terdapat perubahan yang baik terhadap kemampuan menahan kemih (rerata penurunan skala ketidakmampuan: 2,26; SD: 1,4; min-maks: 0-4) dan frekuensi berkemih/mengompol (rerata penurunan frekuensi berkemih: 0,63; minmaks: 0-2).

Senam Kegel memperlihatkan dapat meningkatkan kemampuan berkontrol berkemih pada lansia yang mengalami inkontinensia urin, sehingga disarankan pada lansia untuk melakukan senam Kegel secara rutin karena mudah dan tidak memerlukan alat apa pun serta menjadi aktivitas fisik yang baik selama waktu senggang, jadi dapat dilakukan kapan saja. Intervensi ini menjadi praktik berbasis bukti juga bagi keilmuan sehingga dapat diaplikasikan dalam asuhan keperawatan khususnya ketika berhadapan dengan pasien lansia.

\section{UCAPAN TERIMA KASIH}

Tim penulis mengucapkan terima kasih kepada LPPM Universitas Katolik Musi Charitas yang telah mendanai kegiatan pengabdian ini. Selain itu tim pengabdian mengucapkan terima kasih kepada Lurah Talang Betutu Palembang dan perangkat RT atas kesediaan menjadi mitra, memberikan fasilitas lokasi pengabdian, dan menjadi narahubung kepada warga masyarakat dalam proses pengabdian sehingga dapat terlaksana dengan baik.

\section{DAFTAR RUJUKAN}

Chiacchiero, M., Dresely, B., Silva, U., DeLosReyes, R., \& Vorik, B. (2010). The relationship between range of movement, flexibility, and balance in the elderly. Topics in Geriatric Rehabilitation, 26(2), 148-155. https://doi.org/10.1097/TGR.0b013e3181e854bc

Crisp, J. [Ed], Douglas, C. [Ed], Rebeiro, G. [Ed], \& Waters, D. [Ed]. (2017). Fundamentals of nursing: Australian adaptation. Fundamentals of Nursing: Australian Adaptation.

D.A, D., \& Martiningsih. (2014). Pengaruh Latihan Kegel Terhadap Inkontinensia Urine Pada Lansia Di Panti Sosial Tresna Wherda Mega Angi Bima. Jurnal Kesehatan Prima, I(2), 1292-1297.

Felde, G., Ebbesen, M. H., \& Hunskaar, S. (2017). Anxiety and depression associated with urinary incontinence. A 10-year follow-up study from the Norwegian HUNT study (EPINCONT). Neurourology and Urodynamics, 36(2), 322-328. https://doi.org/10.1002/nau.22921

Firyal, F. R. A. (2017). Hubungan Antara Konsumsi lemak, Obesitas Dan 
Aktovitas Fisik Dengan Hipertensi Usia Monopause. Jurnal Ilmiah Kesehatan Media Husada, 6(1), 47-58. https://doi.org/10.33475/jikmh.v6i1.53

Johan, D. (2011). Pengaruh Senam Yoga Terhadap Penurunan Tekanan Darah Pada Lansia Yang Mengalami Hipertensi Di Wilayah Kerja Puskesmas Air Dingin Padang Tahun 2011. Fakultas Keperawatan Universitas Andalas.

Juananda, D., \& Febriantara, D. (2017). Inkontinensia Urin pada Lanjut Usia di Panti Werdha Provinsi Riau. Jurnal Kesehatan Melayu, 1(1), 20. https://doi.org/10.26891/jkm.v1i1.2017.20-24

Karjoyo, J., Pangemanan, D., \& Onibala, F. (2017). Pengaruh Senam Kegel Terhadap Frekuensi Inkontinensia Urine Pada Lanjut Usia Di Wilayah Kerja Puskesmas Tumpaan Minahasa Selatan. Jurnal Keperawatan, 5(1).

Pranata, L., Koerniawan, D., \& Daeli, N. E. (2019). Efektivitas ROM terhadap Gerak Rentang Sendi Lansia. Proceeding Seminar Nasional Keperawatan, 110-117.

Siburian, P. (2013). Empat Belas Masalah Kesehatan Utama Pada Lansia. Http://artikel.sabda.org/empat_belas_masalah_kesehatan_utama_pada_lansia.

Stanley, M. (2007). Buku ajar keperawatan gerontik (Gerontological Nursing: A Health Promotion or Protection Approach). In Jakarta: EGC.

Strong, N., Salim, S. Z., Nickels, J. L., \& Poduri, K. R. (2017). Urinary incontinence in older adults. In Geriatric Rehabilitation: From Bedside to Curbside (pp. 157-180). https://doi.org/10.1201/9781315373904

Sun, D., \& Agrawal, Y. (2016). Anatomy and Physiology of the Vestibular System. In Sataloff's Comprehensive Textbook of Otolaryngology: Head and Neck Surgery (Otology/Neurotology/Skull Base Surgery) - Volume 1 (pp. 57-57). https://doi.org/10.5005/jp/books/12689_5

Tortora, G. (2009). Principles of Anatomy and Physiology 12th ed - G. Tortora. In John Wiley \& SOns, Inc. (Vol. 53). https://doi.org/10.1017/CBO9781107415324.004

Wente, K., \& Dolan, C. (2018). Aging and the Pelvic Floor. Current Geriatrics Reports, Vol. 7, pp. 49-58. https://doi.org/10.1007/s13670-018-0238-0

Wilis, N. (2018). Inkontinensia, Tugas Keluarga, Tugas Keluarga Dalam Menghadapi Inkontinensia Urine Pada Lansia. Jurnal Keperawatan Malang, 3(1), 7-15. https://doi.org/10.36916/jkm.v3i1.53 